\title{
障子紙の污れについで
}

\section{三井 清・立岩文数・香西定行**}

\section{Studies on Stains on Syôzi-paper}

\author{
Kiyoshi Mii, Humikazu Tateiwa and Sadayuki Kozai
}

(Shikoku Branch of the Osaka Industrial Research Institute, Hananomiya-tyô, Takamatsu-city, Kagawa, Japan)

It has been discussed that rayon paper for Syôzi (Syôzi is a Japanese paper-sliding-door) is stained easily by dust in the air. We studied on that phenomena by the use of a stain-hasten-device by smoke of oil.

The results obtained were as follows:

1) Stains on paper are extremely affected by the air permeability of that paper.

2 ) When the air permeability of paper is more than about $30 \mathrm{sec} . / 200 \mathrm{cc} / 30 \mathrm{sheets}$, stains on that paper are no longer affected by the air permeability of itself.

3) Stains on Syôzi-paper are not affected by the smoothness of it. The fluffs of its surface, however, have an effect on a state of stains owing to smoke of oil.

4) The electrification of Syôzi-paper does not affect on stains on it.

\section{1. 緒言}

ここ数年らい，障子紙にレーヨン繊維がとり入れら れて，いわゆる化繊障子紙としてだんだん製造量も多 くなりつつある。ところがこれは污れがひどいといら ことが言われ出し，この現象に対する解明の要求が高 まってきた。それに応えるものの一端として，障子紙 の污れについて報告する。

障子紙の污れは変色をも含めて，つぎの 3 点の原因 によるものと考えられる。すなわち

(1) 塵埃，油煙などの付着

（2）紙に使用してある増白剤の変色

(3) 紙構成繊維自体の変色

さいきんの障子紙には，増白剂として螢光染料が多 すぎると思えるほど多量に使われており，とくに化緎 障子紙にその傾向が著しいために，螢光染料自身によ る変色がめだってきている。しかし本報ではこれを取 り扱わないで，第 1 項の塵埃，油煙—とくに油煙の 付着による白色度の低下を問題とする。

塵埃，油煙などの付着量の大小は，一応つぎの要因 によるものと考えられる。

(1) 紙の透気性

（2）紙の平滑性

* 原稿受付 39.10 .24

**大阪工業技術試験所四国支所
（3）紙の带電性

本報では以上の三つの要因につき検討したことを述 ベる。

\section{2. 実 験 装 置}

塵埃などの付着現象は，実際の使用状況により判定 するのがもっとも良いと思われるけれども，試験時間 も長くかかるし，多くの試料を同一条件に保つことも 困難なことであるので，第 1 図のような油煙付着促進 装置をつくり実験を行なった。

これは直径 $50 \mathrm{~cm}$ ，高さ $30 \mathrm{~cm}$ の密閉した木製円筒 の中で，中央軸の周りにほぼ鉛直方向に（すこし傾斜 をつけてあるが)，試料を 6 枚保持し，これを一定回 転数で回転させるようにしたもので，この中でモビル 油約 $1 \mathrm{~g}$ を燃焼させ，そのとき出る油煙の中で試料を 回転させる。こうすると試料自身が空気を攪䢁するの で, 油煙は泳ぼ一様に円筒内に分布すると考えられ， かつこの中を試料は，実際の障子紙の使用状態とほぼ 等しい鉛直の姿勢を保ちながら回転することになる。

試料の鉛直方向よりの傾斜は，中の空気を上下方向 に攪拌するためであって，三，三の実験の結果，試料 に付着する油煙がなるべく一様になるような角度を選 定した。試料取付部の下部には薄鉄板製のスカートを

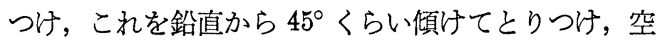
気を下からすくい上げるよらな作用を持たせて，円筒 


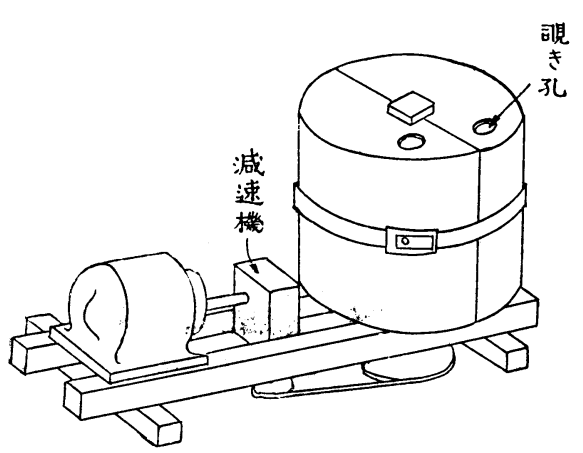

第 1 図実

内の空気の上下方向の攪拌を助けさせる。

このような試験状態と障子の実際状態とを比較する と, 実際状態においては障子は鉛直に立って静止して おり，空気はそれに衝突して表面に沿って流れるか， あるいはそれを透過して反対側に出るのに対し，この 試験状態に执いては, 空気中を試料が運動し, 自ら空 気衝突してその表面に空気を流れさせ, あるいは空 気を裏面に透過させるといらことになる。従って空気 と紙との相対的関係はほぼ等しいと考えてよいので, このような装置を作ることにしたのである。

試料寸法は $40 \mathrm{~mm} \times 250 \mathrm{~mm}$ で，両端取付部を除く と実際の污れの面積は $40 \mathrm{~mm} \times 200 \mathrm{~mm}$ である。幅が $40 \mathrm{~mm}$ 以上になると，回転の中心部と周辺部とで污れ 飞差がでてくるようになる。

試料取付軸の回転は, 最初モビル油 (30 番) を燃焼

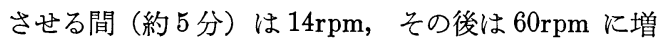
加して 25 分, 合計 30 分間としている。

モビル油は，径 $25 \mathrm{~mm}$, 高さ $30 \mathrm{~mm}$ の小さな磁製る つぼの中に入れて燃やしたが，ある時間燃焼すると自 然に消える。従って燃焼量を自由にコントロールする のは困難であり，この点改善の余地がある。燃焼量は 燃焼前後の重量差である。

以上の上うにして紙に油煙を付着させるが，その污 れの程度を表わすには白色度の低下を以てした。すな わち污れ前の反射率と污れ後の反射率とを測定し, そ の差をとる。この差の数值は視感による污れの度合に 関連し, その差の数值と元の反射率の数値との比は, 油煙の付着量に関連するものと考兄られる゙，いずれ をとるも大差はないので，以下主として差の数値をと ることにした。使用した白度計は積分球式のもので, 照明および受光の幾何学的条件は, 垂直照射, 拡散受 光 (JIS の条件II) のものである。以上データの反射 率の数值は, 同機の青色フィルタによる反射率の数值 そのままであり，かつ紙 1 枚を裏面黒紙で測定してい
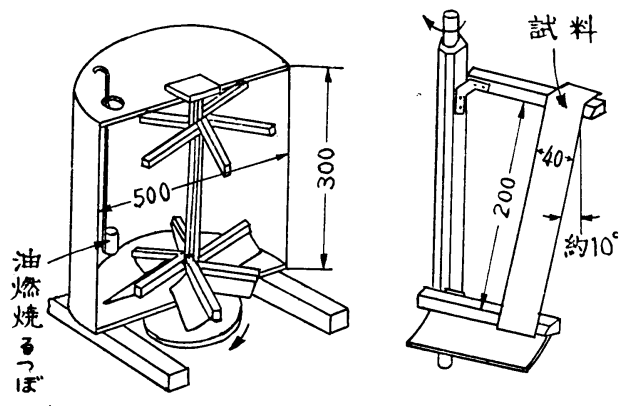

験装置

るので，これからただちにハンター白色度に変換する ことはできない。

な扮透気度測定にはガーレデンソメータ B 型, 平滑 度測定にはオートマチックベック平滑度測定機を用い た。障子紙の平滑度は測定秒数がひじょうに小さいの で，時間測定にはサイクルカウンタを用い，これから 秒数を出した。

\section{3. 試}

料

使用した試料は第 1 表に示す 12 種である。ここで 透気度は 30 枚重ねて $200 \mathrm{cc}$ の空気通過に要する秒数 を測定したものである。障子紙は透気度が良く，1枚 では測定にかからないのでかく重ねたが，重ね枚数と 秒数との関係をグラフに画くと, 30 枚程度まではほと んどすべて直線となるので, 30 枚重祆の数值から他の 少ない枚数重㸚の数值に換算しても，大した誤差はな いものと思われる。後の実験において, 透気度を調整 するのにその紙の重ね枚数をかえたのは，この考劣に よるものである。

\section{第 1 表 試}

料

\begin{tabular}{|c|c|c|c|c|c|}
\hline 符号 & 銘 & $\begin{array}{l}\text { 坪 量 } \\
\mathrm{g} / \mathrm{m}^{2}\end{array}$ & $\begin{array}{l}\text { 透気度 } \\
\sec / 200 \mathrm{rc} \\
/ 30 \text { 枚 }\end{array}$ & $\begin{array}{c}\text { 平滑度 } \\
\text { sec. }\end{array}$ & 備 \\
\hline A & & 31.6 & 5.0 & 1.9 & 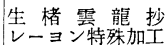 \\
\hline B & テイジ纸 & 35.7 & 4.6 & 1.5 & 化 緎 紙 \\
\hline C & パイロン & 41.4 & 13.5 & 3.6 & 化 繊 \\
\hline $\mathrm{D}$ & 梅の白雪 & 38.9 & 25.4 & 4.0 & 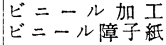 \\
\hline $\mathrm{E}$ & 青 & 38.2 & 20.0 & 2.9 & 正 \\
\hline $\mathrm{F}$ & 不 & 42.2 & 45.3 & 3.1 & \\
\hline $\mathrm{H}$ & ロンクリン & 46.6 & 17.0 & 3.7 & レーヨン抄 \\
\hline I & $\checkmark ミ ロ V$ & 39.8 & 4.5 & 1.4 & 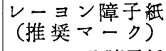 \\
\hline $\mathrm{K}$ & フクロン & 33.6 & 9.7 & 2.2 & レーヨンス障子維 \\
\hline $\mathrm{L}$ & ミキロン & 45.4 & 6.0 & 1.7 & 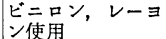 \\
\hline $\mathrm{N}$ & 紅 & 39.3 & 39.4 & 7.0 & 寒製一枚撰 \\
\hline 0 & 紙 & 30.3 & 22.6 & 2.7 & 山物, 手 抄 \\
\hline
\end{tabular}




\section{4. 実 験 結 果}

\section{(1) 透気度と污れ}

記号 $\mathrm{A}$ から $\mathrm{F}$ までの 6 種の紙を， $(\mathrm{A} ， \mathrm{~B} ， \mathrm{C})$ のグ ループと（D， E， F) のグループとにわけ，各試料 とも 2 枚つうつ， 1 枚は紙の表を試料の運動の前面にし， 他の 1 枚は裏を運動の前面にしてとりつけ試験した。 結果は第 2 図のと打りである。表と裏とでは反射率の 低下量が多少違っているが，この程度では差があると は言えない。これについては後にまた触れる。

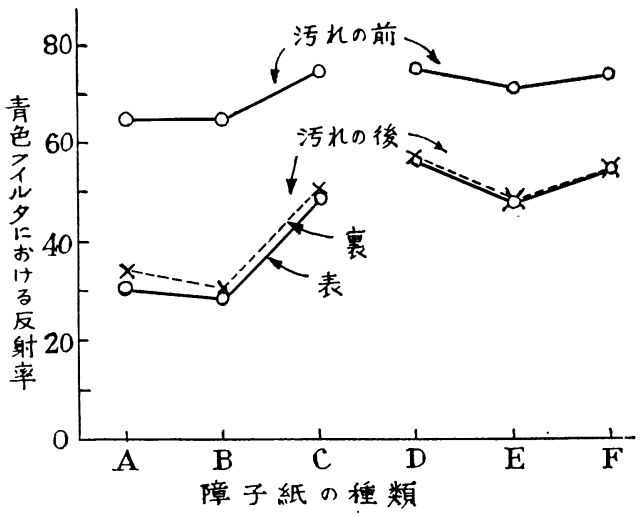

第2図障子紙 1 枚のよごれ (1)

上の結果から透気度と污れとの関係をとると第 3 図 のようになる。これをみると，通気性のよいものほど よく污れることがわかるが，30 sec $/ 200 \mathrm{cc} / 30$ 枚程度以 上の秒数のものは，污れ量が一定になると言えそうで 亦る。

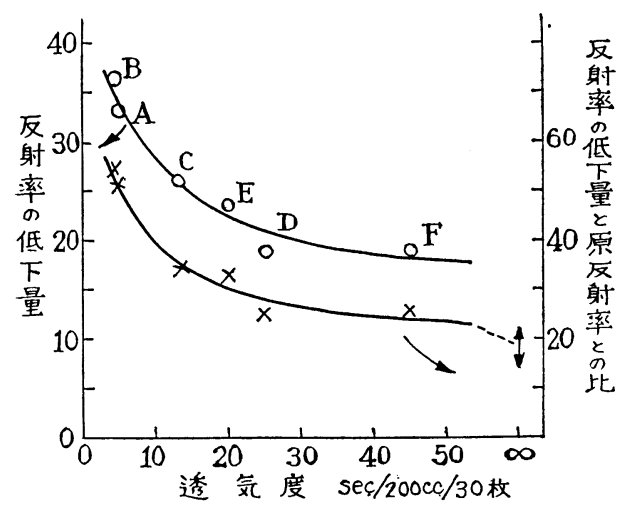

第3図透気度と污れ (1)

第 $4 ， 5$ 図は，第 $2 ， 3$ 図の実験を繰返したものであ るが，結果は注とんど同一である。

つぎ試料の裏にガラス板を密着させて試験した結 果は第 6 図のと扮りである。これは各試料の通気性を まったくなくした場合と考光られるが，この場合の反

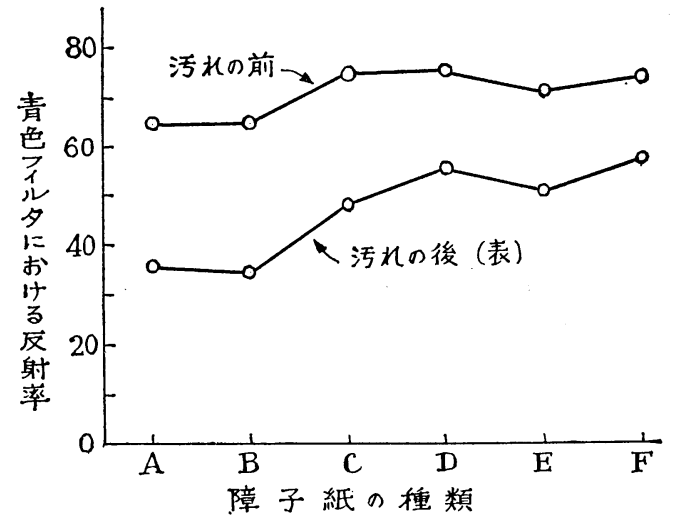

第4図障子紙 1 枚の.でれ（2)

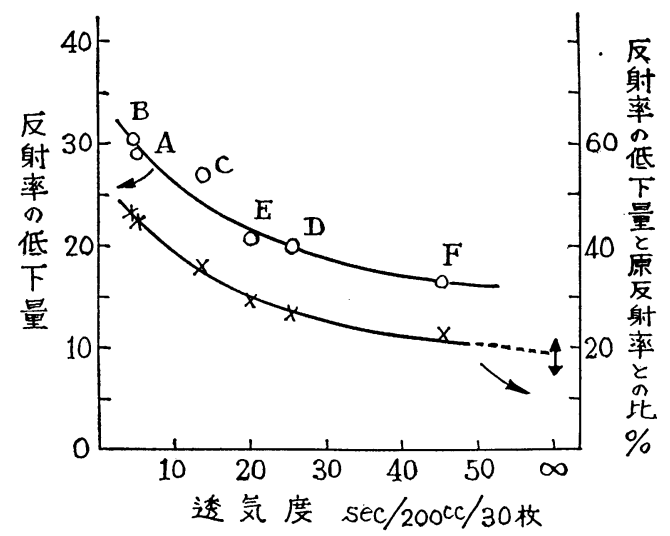

第5図透気度と污れ(2)

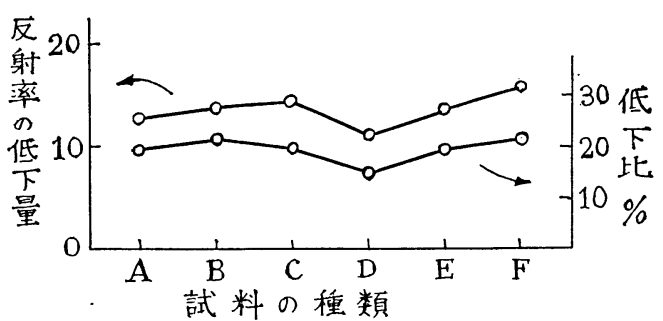

第6図 通気性のないとさの污れ

射率の低下量は，各試量とも大差なしとみられる。 第 3 図，第 5 図中にこの結果を書きこんだのが，透気 度秒数ののところに示してある知印の範囲であって, 扮扮むね同一カーブの上借っているのがわかる。

以上の実験は，まったく別の性質を持つ紙について 行なったものであるから，通気性以外の紙質が影響し ているかもわからない。それで同一の紙を用い，その 重效数を变劣て透気度を変え，污れとの関係を調へ た結果が第 7 図である。試料として化瀻紙 2 種（B $\mathrm{L})$, 楮紙 1 種 $(\mathrm{E})$ を用い，カーブの下の（）内に 
示したように枚数を変え，透気度を変えたものである。 試料B 1 にはなにか異状な点がみられるが，これを除 外して考えると，透気度が $1 \mathrm{sec} / 200 \mathrm{cc}$ 以上はほぼ同 程度のよごれがつくもののようである。この結果は第 3 図に和ける $30 \mathrm{sec} / 200 \mathrm{cc} / 30$ 枚の点に相当し, 両者 一致した結果が得られる。（）内のところにガラス とあるいは, 裏面にガラスをあてた場合で, 透気度秒 数がめと考えられる点を示す。このグラフにおいて， 各カーブの間に反射率低下量の差がみられるが，これ はモビル油然焼量が異なったためであって各カーブ間 の比較をするのは妥当ではない。

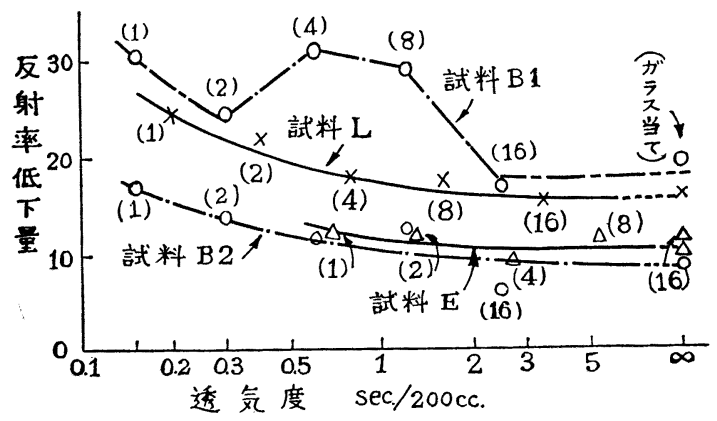

第7図 同一紙に和恬る透気度と污れ

\section{(2) 平滑度と污れ}

前項に持いて述べたように，紙の通気性は污れに大 いに関係があるが，こんどは紙の平滑度がどのように 関係するかにつき実験を行なった。

まず異なった紙の透気度を等しくするために，その 紙の重ね枚数をかえて透気度を等しくするよう調整し た。污れの試験結果は第 8～10 図に示すとおりである。 第 8 図に打いては，A〜 F の試料を図面中に記入の枚 数だけ重ね合わせ，透気度を $2 \mathrm{sec} / 200 \mathrm{cc}$ にしたもの であり，第 9 図は $4.5 \mathrm{sec} / 200 \mathrm{cc}$ ，第 10 図は $9 \mathrm{sec} / 200$

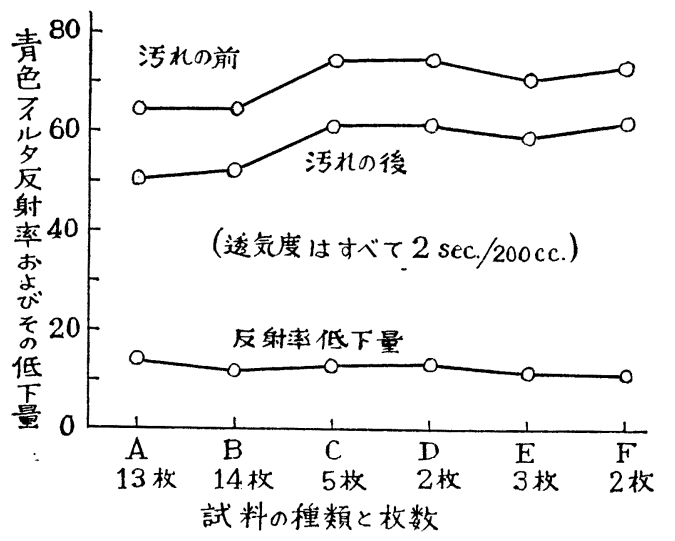

第 8 図 透気度を等しくしたときの污れ (1) ccにしたものである。いずれも反射率低下量は大差 なく，実験誤差範囲内にあるものと考えられる。

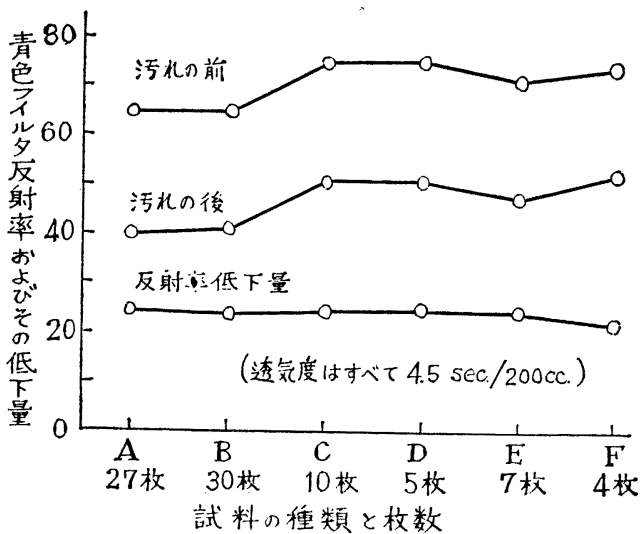

第9図 透気度を等しくしたときの污れ (2)

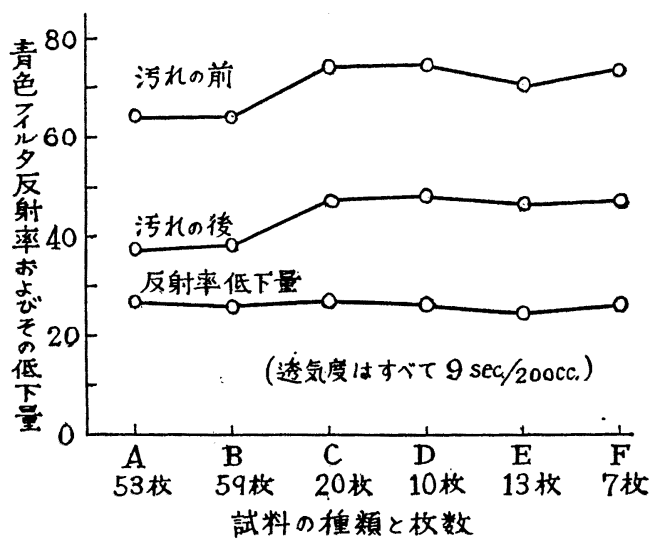

第 10 図 透気度を等しくしたとさの污れ (3)

上の結果に拈ける反射率低下量が，紙の表面のあら さ，すなわら平滑度に関連があるかどらかをみたのが 第 11 図である。なお前出の第 6 図の“通気性のない ときの污れ”のカーブを，表面平滑度に関連させてひ き直したものも第 11 図中に記入してある。いずれも

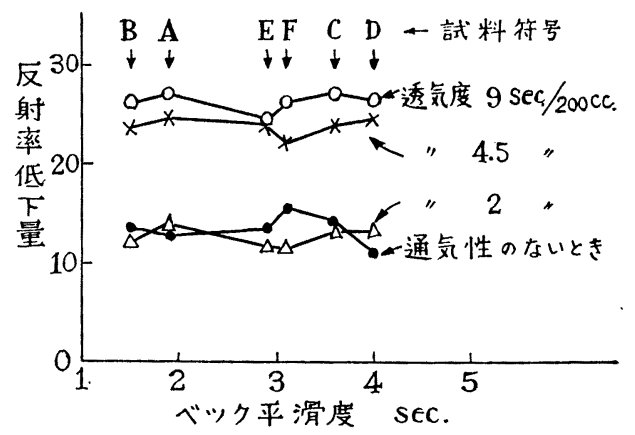

第 11 図平滑度と污れ(1) 
污れが平滑度に関係ありとは言えない状態である。

ついで紙の重敉枚数もかえず透気度もかえず, 紙の 表面の状態のみ変えるために, 異なった紙 3 種 $\mathrm{A}, \mathrm{B}$ Cを，(ABC)，(B CA)，(CAB）といらょうに重 ね順序をかえて試験した結果が第 12 図である。試数 を各 1 枚づつ重ねた場合，2枚づつ重ねた場合，4枚 づつ重ねた場合の 3 回行なっているが，これらは同一 回次に拈いてはいずれも透気度は相等しく, 表面の紙 のみが異なっているわけである。これから得られた污 れの結果を, 表面の紙の平滑度と関連させてグラフを 画いたのが第 12 図である。図中の線分はその試験片 の最大值と最小值との範囲を示す。またこの試験は数 回に分割して行な⿱れれたが，いずれも同一の污れ試験 片を入れ，その反射率低下量から他の試料のそれを補 正したから，近似的に全部同一回次に試験したものと みなすことができる。この結果をみても，平滑度と污 れとの間に相関ありということはできない。

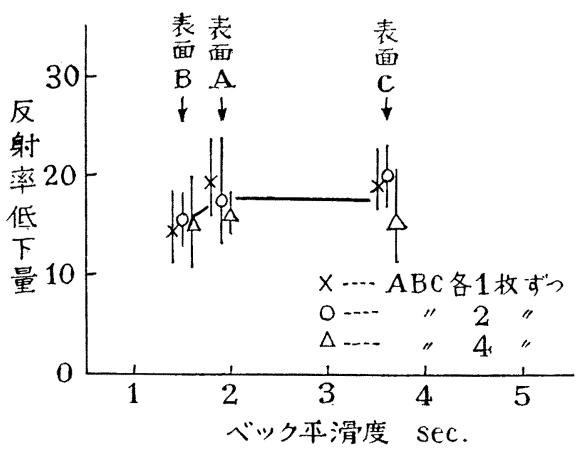

な扮前出の第 2 図, 第 4 図に括いて, 紙の表を試料 運動の前面にしたときと, 紙の裏を運動の前面にした とさと, 前者と比べて後者のほうが反射率低下量が少 ないといら結果がでているが，この際の污れかたをよ く観察すると, 裏の方は繊維がケバ立っており, 油煙
第 12 図平滑度と污れ(2)

はその尖端にあらく数少なく付着しており，表の方は なめらかな表面にこまかく一様に付着しているといら 差が見受けられる。この現象はほかにもみられ, 上質 印刷紙のように滑らかな紙面では，こまかい油煙が一 様に全体につき，ザラ紙のような粗い紙面には，大き な油煙のみが少なくつき, 白度計にかけてみると, 後 者の方が反射率低下量がむしろ少ないといら結果が得 られる（低下量の原反射率に対する比をとうてみても 同様)。このよらに平滑度が大きく異なると, 污れぐ あいも違ってくるけれども，ここで対象としている障 子紙の範囲では，平滑度は污れに関係ありとはいえな よいらである。

\section{（3）带電泾と污れ}

実際使用上からいって，化繊紙の方が普通紙より污 れかたが大さいといら点から，化繊紙のほらが带電性 が大きいからではないかという考が出てくる。そこで 帯電防止剂で処理して带電しにくくした紙と, 無処理 のものとを比較して実験を行なった。もし帯電性の影 響があるならば，処理した紙は無処理のものと比べて 污れが少なくなるはずである。

使用した帯電防止剂はつぎのと和りである。

a ）タフロン $902 \mathrm{~S}$ 第一工業製薬製, 両性形カチ オン, 微黄色ペースト状, 常温にして $1.5 \%$ 水溶液に して，数秒間浸漬またはスプレー吹付け，自然乾燥を した（略号をTとする）。

b ） 花王ソフター 花王石襝製, 帯電防止柔軟仕 上剂, 淡青色ペースト状，常温にて $0.2 \%$ 水溶液に数 秒間浸漬またはスプレー吹付け，自然乾燥をした（略 号をSとする)。

試料は化繊紙 3 種 $(H, I, K)$, 普通紙 2 種 $(N$, O）を用いた。これらの透気度の值は，処理後のもの につき測定した值を用い，3.5 sec/200cc になるように 重ね枚数を選定した。従って透気度はすべてほぼ等し いと考えることができる。

試験にあたっては，円筒

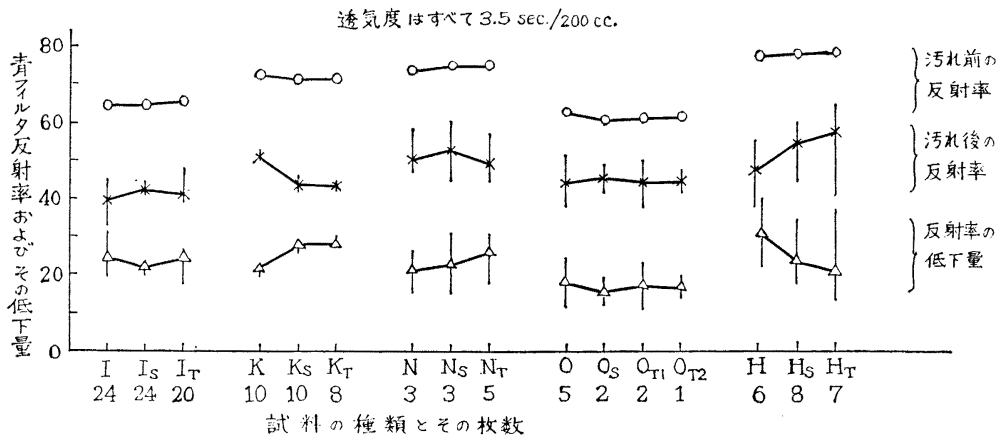

第13図帯電防止処理の有無とその污れ
内の温度を室温より $20^{\circ} \mathrm{C}$ あげて（空気を乾燥させる ため)，60rpm で 3 時間運 転後油煙を発生させた。も し紙が帯電するならば，こ の前操作により十分帯電し ているものと思われる。

結果は第 13 図に示すと 抢りである。図中 I，Kな ぞの文字は試料符号, $\mathrm{I}_{S}$, $\mathrm{K}_{S}$ などはソフターで処理 
第 2 表带電防止処理紙の表面固有抵抗

\begin{tabular}{|c|c|c|c|c|c|c|}
\hline \multirow{2}{*}{ 符号 } & \multirow{2}{*}{ 銘 } & \multicolumn{3}{|c|}{ 表面固有抵抗オ一ム } & \multicolumn{2}{|c|}{ 処理前後の抵抗比 } \\
\hline & & 無処理 $(R)$ & タフロン $\left(R_{T}\right)$ & ソフター $\left(R_{S}\right)$ & $R_{T} / R \%$ & $R_{S} / R \%$ \\
\hline $\mathrm{H}$ & 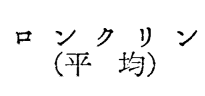 & $\begin{array}{l}9.7 \times 10^{9} \\
9.0 \times 10^{9} \\
9.3 \times 10^{9}\end{array}$ & $\begin{array}{r}10.0 \times 10^{8} \\
7.9 \times 10^{8} \\
9.0 \times 10^{8}\end{array}$ & $\begin{array}{l}6.1 \times 10^{9} \\
6.8 \times 10^{9} \\
6.4 \times 10^{9}\end{array}$ & 9.6 & 68.7 \\
\hline I & $\nabla_{(\text {平 均) }}$ У & $\begin{array}{r}10.2 \times 10^{9} \\
5.6 \times 10^{9} \\
7.9 \times 10^{9}\end{array}$ & $\begin{array}{l}5.6 \times 10^{8} \\
7.9 \times 10^{8} \\
6.8 \times 10^{8}\end{array}$ & $\begin{array}{l}3.8 \times 10^{9} \\
7.0 \times 10^{9} \\
5.4 \times 10^{9}\end{array}$ & 8.5 & 68.2 \\
\hline K & 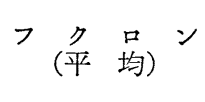 & $\begin{array}{l}9.9 \times 10^{9} \\
9.0 \times 10^{9} \\
9.5 \times 10^{9}\end{array}$ & $\begin{array}{l}6.1 \times 10^{8} \\
6.8 \times 10^{8} \\
6.4 \times 10^{8}\end{array}$ & $\begin{array}{l}7.2 \times 10^{9} \\
7.0 \times 10^{9} \\
7.1 \times 10^{9}\end{array}$ & 6.8 & 75.1 \\
\hline $\mathrm{N}$ & 紅 (平 均) & $\begin{array}{l}2.4 \times 10^{9} \\
3.0 \times 10^{9} \\
2.7 \times 10^{9}\end{array}$ & $\begin{array}{l}6.6 \times 10^{8} \\
6.5 \times 10^{8} \\
6.6 \times 10^{8}\end{array}$ & $\begin{array}{l}2.3 \times 10^{9} \\
3.0 \times 10^{9} \\
2.7 \times 10^{9}\end{array}$ & 24.4 & 96.0 \\
\hline 0 & 紙 (平 均) & $\begin{array}{l}3.9 \times 10^{9} \\
3.5 \times 10^{9} \\
3.7 \times 10^{9}\end{array}$ & $\begin{array}{l}4.5 \times 10^{8} \\
4.6 \times 10^{8} \\
4.6 \times 10^{8}\end{array}$ & $\begin{array}{l}2.0 \times 10^{9} \\
2.0 \times 10^{9} \\
2.0 \times 10^{9}\end{array}$ & 12.2 & 53.8 \\
\hline
\end{tabular}

した試料 $\mathrm{I} ， \mathrm{~K}$ 等を示し， $\mathrm{I}_{T} ， \mathrm{~K}_{T}$ などはタフロンで 処理したものを示す。これによってみると，帯電防止 処理の有無による污れの差は認められない。

ところで以上のように処理した試料が，はたして帯 電防止効果を持つものであったかどうかについては, その表面固有抵抗を測定してみればわかる。その結果 は第 2 表のと抢りで，ソフターよりもタフロンのほう が成績がよく, 普通紙よりも化瀻紙の汪うに上く效い ているといら差はあるけれども，いずれも良く効果を 現わしており, 処理後の化纎紙の表面抵抗は, 無処理 の普通紙の表面抵抗と，同程度かあるいはより低い。

以上のことによって，これらの紙の帯電性が，污れ の多少に影響を及ぼすものとは考光られない。

\section{4. 総 括}

油煙による污れ促進装置を使用して，障子紙の污れ の現象につさ実験した結果は

(1) 污机は透気度に大いに関係する。

（2）透気度秒数が $30 \mathrm{sec} / 200 \mathrm{cc} / 30$ 枚程度より大き くなると，污れは透気度に関係しなくなる。

(3) 紙の平滑度は障子紙に括ける程度の差では污れ 関係しない。ただし，紙の表面汹括るケバ立ちは 油煙の付着ぐあいに影響がある。

（4）紙の帯電性の污れに対する影響は，障子紙の範 囲においてはない。

最後に試料準備に御尽力くださった岐阜県製紙試験 場に感謝する。 (p.40よりつつくく)

ている現状である。手漉改良半紙の需要量は昭和 14 年 3,500 トンと推定される。

三㯨紙の新しい一つの方向としてその物理的光学的 特長を生かし，合成高分子とのコンビネーションも考 它れよう。

\section{5. 総 括}

駿河半紙の原料, 紙料調製抄造法の各工程について 科学技術および技術史的見地から検討した。

改良半紙の抄造法品質について検討した。

終わりに臨み貴重な試料をご恵与下された製紙博物
館長成田潔英先生に深く感謝の意を表します。

\section{参考 文 献}

1） 前松，本誌，10，620６25（昭 31）

2) 関彪，紙業雑誌，大正 7 年 2 月

3）佐藤輝雄，「岳南吉原」p. 4 5，1951（富士南部 商工会議所版）

4）柘植清，紙業雑誌，35，No. 1，6（昭 15）

5) 村山敏夫，本誌，10, 302～304（1956）

6) 下田功, 林産科学, 4, 106 (1946)

7）町田，錦織，紙八技協誌，17, 108 (1963)

8）前松：未発表 